\title{
Hyperthyroidism and immune thrombocytopenia
}

\author{
PETER JACOBS* $\dagger$ \\ M.D., Ph.D.
}

FRANCOIS MAJOOS $\dagger$
M.B., B.Ch.

\section{AUGUSTINE PERROTTA $\ddagger$ D.O.}

\begin{abstract}
*University of Cape Town Leukaemia Centre, †Department of Haematology, Groote Schuur Hospital, Observatory, Cape, and $\ddagger$ Michigan State University College of Osteopathic Medicine, Lansing, Michigan, U.S.A.
\end{abstract}

\begin{abstract}
Summary
Hyperthyroidism and immune thrombocytopenia occurred concurrently in five patients; in a sixth, thyrotoxicosis developed after successful treatment of the thrombocytopenia. Correction of the hyperthyroidism was followed by a variable pattern of clinical response. In one case with mild asymptomatic thrombocytopenia spontaneous complete remission occurred. Two patients required adrenocorticosteroids to control severe thrombocytopenic purpura during the period of hyperthyroidism, after which complete remission occurred. Another patient with severe symptomatic thrombocytopenia remains with a partially compensated thrombocytolytic state but is without purpura and off all therapy. A fifth patient required splenectomy for drug-resistant thrombocytopenia and remains critically dependent on immunosuppressive therapy. The sixth patient had a relapse of immune thrombocytopenia with subsequent development of thyrotoxicosis but platelet count spontaneously returned to normal after correction of the hyperthyroidism. Pregnancy in two of these six patients was not associated with recurrence of either hyperthyroidism or thrombocytopenia.

Management of symptomatic purpura in adults with co-existent hyperthyroidism may differ from that customarily employed since adrenocorticosteroid therapy may need to be extended until euthyroidism has been established before proceeding to splenectomy. When surgery is necessary, the risk of thyrotoxic storm should be anticipated, and the patient appropriately premedicated.
\end{abstract}

KEY WORDS: corticosteroid therapy, splenectomy, pregnancy, autoimmunity.

Correspondence: Professor Peter Jacobs, Department of Haematology-Research Centre, University of Cape Town Medical School, Anzio Road, Observatory 7925, Cape, Republic of South Africa.

\section{Introduction}

Acute haemorrhagic purpura with exophthalmic goitre was recognised more than half a century ago (Jackson, 1931), and their co-existence subsequently confirmed (Toland and Askey, 1931; Dennig, 1933). In a series of 49 cases reported by 1978 (Herman, Resnitzky and Fink, 1978) adequate treatment of hyperthyroidism resulted in platelet counts returning to normal in a significant number of individuals.

Although an association has been described between idiopathic thrombocytopenia and a number of other autoimmune processes (Oren and Cohen, 1978; Pinals et al., 1977; Segal and Weintraub, 1976; Clancy, Muller and Ward, 1974; Friedland and Schaefer, 1980; Branehög et al., 1979), the mechanism by which they are related remains controversial. There appear to be underlying links at the major histocompatibility locus (Remuzzi et al., 1977) and it has been suggested that the final common pathway involves cell surface receptors (Stobo, 1981). The evidence for a common immunological mechanism includes the demonstration of elevated antiplatelet immunoglobulin levels in patients with Graves' disease and Hashimoto's thyroiditis, with the highest values being found in the presence of thrombocytopenia (Hymes et al., 1981). Furthermore, raised triiodothyronine levels are associated with shortened platelet survival and accelerated clearance of heatdamaged red cells from the circulation, suggesting that thrombocytopenia in Graves' disease may be the consequence of peripheral sequestration of antibody coated cells in the reticuloendothelial system (Kurata et al., 1980).

From these observations it is reasonable to anticipate that correction of the hyperthyroidism might influence both the natural history of immune thrombocytopenia and response to adrenocorticosteroid 
therapy, splenectomy, or immunosuppressive drugs. We therefore studied six individuals in whom both of these two autoimmune conditions occurred.

\section{Materials and methods}

\section{Laboratory investigations}

The haemoglobin, red cell count and indices, white cell and platelet counts were determined on the Coulter Counter, Model S Plus (Rowan et al., 1979). Platelet size distribution curves were determined on the Coulter Counter and channelizer (Nelson and Kehl, 1981; Bessman, Williams and Gilmer, 1981). Triiodothyronine $\left(T_{3}\right)$, thyroxine $\left(T_{4}\right)$ and radioiodine uptake were carried out using standard methods (Larsen, 1976). Platelet membrane associated immunoglobulin was determined by complement-lysis inhibition assay (Dixon, Rosse and Ebbert, 1975), the screening tests for collagen vascular disease included measurements of serum total complement (McLean et al., 1978), complement components (McLean et al., 1978), plasma immunoglobulin by electrophoresis (Smith, 1976), and immunoglobulin by nephelometry (Anderson et al., 1971). Bone marrow studies included aspiration and trephine biopsy (Bird and Jacobs, 1983).

\section{Patients}

Case 1: A 52-year-old woman presented with a 2month history of easy bruising. She had been losing weight for 8 months despite a good appetite, stools were loose, and in the 3 months before admission had developed a preference for cold weather and started to sweat excessively. On examination she was tense and irritable, with a pulse of $120 / \mathrm{min}$ and a fine tremor of her hands. There was diffuse firm enlargement of the thyroid gland which was considered to be multinodular.

Haemoglobin was $12 \mathrm{~g} / \mathrm{dl}$ with normal red cell indices, white cell count and differential. Platelet count varied between 50 and $90 \times 10^{9} / 1$ and size distribution curve showed increased megathrombocytes (Garg, Amorosi and Karpatkin, 1971). Platelet membrane associated immunoglobulin was $43 \mathrm{ng} / 10^{6}$ platelets (normal 5-15). Bone marrow megakaryocytes were increased in number. Iron, folate, and vitamin $B_{12}$ levels were normal. Hyperthyroidism was confirmed by $T_{3}$ resin uptake of $48 \cdot 1 \%$ (normal range 25-37), tri-iodothyronine of $230 \mathrm{ng} / \mathrm{dl}$ (normal range 70-190), thyroxine of $17 \cdot 1 \mu \mathrm{g} / \mathrm{dl}$ (normal range 4-12), $6 \mathrm{hr}$ radioactive iodine uptake by the thyroid at $70 \%$ and 24 hour level of $82 \%$ (normal range 10-25\%). The patient was treated with $5 \mathrm{mCi}$ of radioactive iodine and in the course of 3 months clinical and biochemical euthyroidism was re-established. Platelet count rose spontaneously to $196 \times 10^{9} / 1$ and remains normal.

Case 2: A 23-year-old woman presented 2 months after delivering a normal child with a 1-month $\Rightarrow$ history of easy bruising and petechial bleeding: there $\stackrel{5}{\rightarrow}$ was no antecedent drug ingestion. Platelet count was $9 \times 10^{9} / 1$ and bone marrow showed abundant megakaryocytes. The patient was treated with $30 \mathrm{mg} \frac{\bar{\omega}}{\vec{D}}$ prednisone daily. At that time she volunteered $\unrhd$

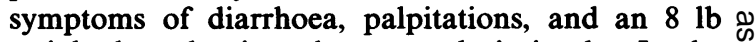
weight loss despite adequate caloric intake. In the course of the next 3 weeks platelet count rose to $40 \times 10^{9} / 1$ but the patient remained critically steroid dependent. In addition, she developed exophthalmos, increasing sweating and nervousness. Hyperthyroid- 8 ism was suspected and the patient was transferred to 3 the care of one of us (AP).

Examination showed mild exophthalmos, lid lag, and a diffusely enlarged thyroid gland. Haemoglobin was $13.6 \mathrm{~g} / \mathrm{dl}$ with normal indices, white cell count os and differential. Platelet count was $55 \times 10^{9} / 1$ and bone marrow showed abundant megakaryocytes. 을 Screening test for collagen vascular disease was negative. Hyperthyroidism was confirmed with a $O$ triiodothyronine level of $49 \mathrm{ng} / \mathrm{dl}$, thyroxine of 22 $\mu \mathrm{g} / \mathrm{dl}$, and a radioactive iodine uptake of $68 \%$ at $2 \mathrm{hr}$, $82 \%$ at $6 \mathrm{hr}$, and $72 \%$ at $24 \mathrm{hr}$.

The patient was continued on $60 \mathrm{mg}$ of predniseo lone daily and hyperthyroidism treated with $160 \mathrm{mg}$. of propranolol daily and $10 \mathrm{mCi}$ of radioactivo iodine. Within 6 weeks the patient was clinically and biochemically euthyroid and platelet count was over $200 \times 10^{9} / 1$. All therapy was discontinued and the platelet count remains normal. The patient has since had a further uneventful pregnancy and both mother and child had normal platelet counts at delivery.

Case 3: A 41-year-old woman was seen because of a chest pain. There was no history of drug ingestion or family history of thyroid disease or thrombocytopenia. On examination the patient was anxious and clinically thyrotoxic. Haemoglobin was $11.8 \mathrm{~g} / \mathrm{dl}$ with normal indices, white cell count, and differential. Platelet count was $17 \times 10^{9} / 1$ and platelet-bound immunoglobulin $15 \mathrm{ng} / 10^{6}$ platelets. Bone marrow showed abundant megakaryocytes. The hyperthyroidism was confirmed with a triiodothyronine level of $380 \mathrm{ng} / \mathrm{dl}$ and a thyroxine level of $34 \cdot 8 \mathrm{ug} / \mathrm{dl}$.

The chest pain was established as due to severe coronary artery disease aggravated by hyperthyroidism and the asymptomatic thrombocytopenic purpura was incidental. The hyperthyroidism was treated with $10 \mathrm{mCi}$ of radioactive iodine and the thrombocytopenia treated with $60 \mathrm{mg}$ of prednisone. Within 2 months the patient was clinically and biochemically euthyroid and the platelet count was normal. Corticosteroids have been withdrawn and complete remission persists. The chest pain has 
improved and the patient is to undergo coronary artery bypass surgery.

Case 4: A 30-year-old woman presented with a 4month history of recurrent epistaxis and spontaneous gingival bleeding following 2 months after an uneventful second pregnancy. There was associated marked fatigue and a $60 \mathrm{lb}$ weight loss, profuse sweating, palpitations and heat intolerance. The patient was anxious and mild exophthalmos, petchiae, and ecchymoses were present. The thyroid gland was symmetrically enlarged, deep reflexes were increased, and a fine tremor of the hands was evident. Haemoglobin was $8.7 \mathrm{~g} / \mathrm{dl}$ with hypochromic and microcytic red cell indices; white cell count and differential were normal. Platelet count was $4 \times 10^{9} / 1$. The bone marrow showed abundant megakaryocytes. Screening tests for collagen vascular disease were negative. Hyperthyroidism was confirmed with a triiodothyronine of $430 \mathrm{ng} / \mathrm{dl}$, thyroxine of 26 $\mu \mathrm{g} / \mathrm{dl}$, and radioactive iodine uptake by the thyroid of $36 \%$ at $2 \mathrm{hr}, 64 \%$ at $6 \mathrm{hr}$, and $69 \%$ at $24 \mathrm{hr}$.

The patient was started on prednisone and treated with $13 \mathrm{mCi}$ of radioactive iodine. Within 10 days the platelet count was normal and the patient clinically and biochemically euthyroid. Platelets remain between 40 and $80 \times 10^{9} / 1$ and the increased number of megathrombocytes demonstrates the presence of a compensated thrombocytolytic state.

Case 5: A 41-year-old male presented with an influenza-like illness, symptoms of anaemia and a purpuric eruption. Haemoglobin was $12 \cdot 8 \mathrm{~g} / \mathrm{dl}$ with normal red cell indices, white cell count, and differential. Platelets were $11 \times 10^{9} / 1$. Marrow showed abundant megakaryocytes. Platelet membrane associated immunoglobulin was $60 \mathrm{ng} / 10^{6}$ platelets. The patient was initially started on prednisone, $60 \mathrm{mg} /$ day and, in view of a poor platelet response, underwent splenectomy. On the day of the operation the patient was, for the first time, noticed to have sinus tachycardia and sweating, and a diagnosis of hyperthyroidism was confirmed by triiodothyronine level of $350 \mathrm{ng} / \mathrm{dl}$ and thyroxine level of $20 \mu \mathrm{g} / \mathrm{dl}$. The thyrotoxic crisis was treated with Lugol's iodine and $30 \mathrm{mg}$ of carbimazole daily.

Although this patient became clinically and biochemically euthyroid, he persisted with thrombocytopenia with bleeding and a prolonged trial of low-dose prednisone and cyclophosphamide have thus far been without effect. There is no evidence of residual splenic tissue and antiplatelet antibodies remain raised.

Case 6: A 21-year-old woman was seen with bleeding gums, haemoptysis and purpura. The diagnosis of immune thrombocytopenia was established on the presence of megathrombocytes and abundant megakaryocytes in the marrow. Screens for collagen vascula disease were negative. There was a poor response to corticosteroids and splenectomy was followed by a slow rise of platelet count to normal. One year later the patient developed a butterfly rash on her face and serologic tests for systemic lupus erythematosus became positive. Because of a fine tremor and weight loss, hyperthyroidism was considered and confirmed with a triiodothyronine of 46.5 $\mathrm{ng} / \mathrm{dl}$, thyroxine of $23 \cdot 1 \mu \mathrm{g} / \mathrm{dl}$, and radioactive iodine uptake of $67 \%$ at $6 \mathrm{hr}$ and $87 \%$ at $24 \mathrm{hr}$. Platelet count was found to be $90 \times 10^{9} / 1$. The patient responded to carbimazole and, with correction of thyrotoxicosis, platelet count returned to normal: no further treatment has been necessary.

\section{Discussion}

These six cases further illustrate the association between immune thrombocytopenia and hyperthyroidism (Herman et al., 1978; Pinals et al., 1977; Valenta et al., 1982). Although the mechanism linking these two syndromes is uncertain, there is evidence in support of a common autoimmune process involving both humoral and cellular abnormalities. Furthermore, in both Graves' disease and Hashimoto's thyroiditis (Hymes et al., 1981) elevated platelet-bound immunoglobulin is found. Should correction of the hyperthyroidism reverse the elevated immunoglobulin levels, it may alter the natural history of the haemostatic defect and therefore modify treatment with immunosuppressive drugs or splenectomy. The patterns of response in our patients following correction of their hyperthyroidism support this theoretical contention.

In two patients there was requirement for adrenocorticosteroids until the patient became euthyroid, at which time medication was discontinued without subsequent relapse. A different response was a partially compensated thrombocytolytic state with a suboptimal platelet count, although further therapy was not necessary. In a further patient correction of hyperthyroidism did not influence platelet count, and the response to adrenocorticosteroids was transient so that splenectomy was unavoidable. Our experience with this patient emphasizes the risk of developing thyroid storm or crisis and patients requiring surgical procedures should be considered to be at risk from such a complication (Schermer et al., 1980).

These patterns of response may be explained by reversal of abnormal capillary fragility (Thompson, 1964), decrease in the sequestration of antibodycoated platelets in the reticuloendothelial system which had been stimulated by increased levels of thyroid hormone (Kurata et al., 1980) or reduction in elevated membrane-associated platelet immunoglobulin (Hymes et al., 1981). It remains an unresolved issue as to whether more than one of these independent processes may be operative simultaneously and 
that each may be influenced by the adrenocorticosteroids, in contrast to the concept that the thrombocytopenia is simply a consequence of the hyperthyroidism (Takeda et al., 1973; Dunlop, McFarland and Lutcher, 1974; Vannasaeng, Wasi and Tandhanand, 1975; Resnitsky, Schonfeld and Dassa, 1979).

The influence of pregnancy on the course of autoimmune diseases is relevant (Jones, 1979). In immune thrombocytopenic purpura the child may be at risk and, wherever possible, platelet counts require correction before delivery. In our experience highdose corticosteroids, vincristine, and intensive plasma exchange offer a realistic alternative to emergency splenectomy. The relative merits of caesarean section as opposed to vaginal delivery, assisted with forceps if necessary, have also not been clearly resolved. Conversely, it is recognized that thyroid function may be disturbed in pregnancy but in neither of our two patients was there exacerbation of hyperthyroidism with subsequent pregnancy and no evidence of relapse of immune thrombocytopenia.

It is concluded that an association exists between the two autoimmune diseases of idiopathic immune thrombocytopenia and Graves' disease, although a genetic basis for this has not been established. In both, humoral and cellular mechanisms are active and, while concurrent manifestations appear the most common, one or other of the syndromes may be less evident at presentation or occur subsequently in the patient's clinical course. The importance of recognizing the association lies in management since, in four of our six patients, the haemostatic abnormality was permanently reversed by correcting the hyperthyroidism. It therefore seems reasonable to recommend that adrenocorticosteroids be persisted with until such time as the patient has been euthyroid for 4 weeks before considering the need for additional immunosuppressive therapy or splenectomy. This approach is in contrast to individuals with imune thrombocytopenic purpura where hyperthyroidism is not present and in whom earlier operation is usually considered.

\section{Acknowledgments}

Supported by the University of Cape Town Leukaemia Centre and Staff Research Fund, the Medical Research Council and the National Cancer Association. We thank Chief Professional Nurse Miss Lucille Wood for help with data collection, Sheila Katcher and Keren Edwards for bibliographic assistance, and Jackie Davies for typing. We thank Dr Hilde Jacob and Dr L. M. Kernoff for patient referral, Mrs Erica Malan for platelet immunoglobulin measurement, and the Medical Superintendent of Groote Schuur Hospital for permission to publish.

\section{References}

Anderson, S.G., Bangham, D.R., Batty, I., Becker, W., CinaDeR, B., VAN DeR GIessen, M., Hymes, F., LONG, D., Peetoom,
F., Pondman, K., Raynaud, M., Reimer, C.B., Rowe, D.S., SCHWICK, H.G. \& VRANCHEVA, S. (1933) Measurements of concentrations of human serum immunoglobulins. Europear Journal of Immunology, 1, 224.

Bessman, J.D., Williams, L.J. \& Gilmer, P.R. (1981) Mean $\overrightarrow{\vec{C}^{*}}$ platelet volume. The inverse relation of platelet size and count in
normal subjects, and an artifact of other particles. Americare Journal of Clinical Pathology, 76, 289.

BIRD, A.R. \& JACOBS, P. (1983) Trephine biopsy of the bone marrow. South African Medical Journal, 64, 271.

BRANEHOG, I., OlsSON, K.S., Weinfeld, A. \& Domellof, L. (1979)』 Association of hyperthyroidism with idiopathic thrombocytopeni६ purpura and haemolytic anaemia. Acta Medica Scandinavica, 205. 125.

ClANCY, R.L., MULLER, H.K. \& WARD, H.A. (1974) Immunodificiency and grouping with thyrogastric autoimmune disease in $\vec{\omega}$ patients with chronic idiopathic thrombocytopenic purpura o Australian and New Zealand Journal of Medicine, 4, 243.

DENNIG, H. (1933) Thrombopenische purpura nach jodeinnahme. Munchener Medizinische Wochenschrift, 80, 562.

DIXON, R., Rosse, W. \& EBBERT, L. (1975) Quantitative determination of antibody in idiopathic thrombocytopenic purpura: correlation of serum and platelet-bound antibody with clinical response New England Journal of Medicine, 292, 230.

DuNLAP, D.B., MCFARLAND, K.F. \& LUTCHER, C.L. (1974) Graves'G disease and idiopathic thrombocytopenic purpura. American Journal of the Medical Sciences, 268, 107.

FRIEDLAND, M.L. \& SCHAEFER, P. (1980) Hemochromatosis, throm-bocytopenic purpura, and multiple endocrine disturbances. An unusual association of uncommon disorders is reported. Rhode? Island Medical Journal, 63, 342.

GARG, S.K., AMOROSI, E.L. \& KarpatKIn, S. (1971) Use of the megathrombocyte as an index of megakaryocyte number. Ngw England Journal of Medicine, 284, 11.

HeRMAN, J., RESNITZKY, P. \& FinK, A. (1978) Association between thyrotoxicosis and thrombocytopenia. A case report and revievof the literature. Israel Journal of Medical Sciences, 14, 469.

HYMES, K., BLUM, M., LACKNER, H. \& KARPATKIN, S. (1981) Easy bruising, thrombocytopenia, and elevated platelet immunoglobulin $\mathbf{G}$ in Graves' disease and Hashimoto's thyroiditis. Annals of Internal Medicine, 94, 27.

JACKSON, A.S. (1931) Acute hemorrhagic purpura associated with exophthalmic goiter. Journal of the American Medical Association, 96, 38.

JONES, W.E. (1979) Tissue-specific autoimmune diseases in pregnancy. Clinics in Obstetrics and Gynecology, 6, 473.

KuRATA, Y., Nishioeda, Y., Tsubakio, T. \& Kitani, T. (1980). Thrombocytopenia in Graves' disease: effect of T3 on platelet kinetics. Acta Haematologica, 63, 185.

LARSEN, P.R. (1976) Radioimmunoassay of thyroxine, triiodothyro niine, and thyrotropin in human serum. Manual of Clinical ${ }^{\circ}$ Immunology (Eds. N. R. Rose \& H. Friedman), p. 222. American Society for Microbiology, Washington, D.C.

MCLean, R.H., Weinstein, A., Damjanov, I. \& Rothfield, N. 윽 (1978) Hypomorphic variant of $C_{3}$, arthritis, and chronic glomerulonephritis. Journal of Pediatrics, 93, 937.

NELSON, R.B. \& KEHL, D. (1981) Electronically determined platelet indices in thrombocytopenic patients. Cancer, 48, 954.

OREN, M.E. \& COHEN, M.S. (1978) Immune thrombocytopenia, red cell aplasia, lupus, and hyperthyroidism. Southern Medical Jour-N nal, 71, 1577.

PINALS, R.S., TOMAR, R.H., HAAS, D.C. \& FARAH, F. (1977) Graves' N disease, myasthenia gravis, and purpura. Annals of Internal $\mathrm{\omega}$
Medicine, 87, 250 .

RemuZzi, G., Livio, M., Donati, M.B. \& Gaetona, G. (1977) Myasthenia gravis, thrombocytopenia and HLA antigens. Annalso of Internal Medicine, 87, 250.

RESNITSKY, P., SCHONFELD, S. \& DASSA, H. (1979) Effect of Graves' disease on idiopathic thrombocytopenic purpura. Archives of Internal Medicine, 139, 483.

RowAN, R.M., FraZer, G., Gray, J.H. \& MCDonald, G.A. (1979) 
The Coulter Counter Model S Plus-the shape of things to come. Clinical and Laboratory Haematology, 1, 29.

SCHERMer, R.M., MoRley, J.E., ShaRP, B., Daniels, M., HeCt, H., Carlson, H.E. \& Hershman, J.M. (1980) Apathetic thyroid storm association with anasarca and thrombocytopenia. Journal of the American Medical Association, 243, 2485.

SEgAL, B.M. \& WeINTRAUB, M.I. (1976) Hashimoto's thyroiditis, myasthenia gravis, idiopathic thrombocytopenic purpura. Annals of Internal Medicine, 85, 761.

SMITH, I. (1976) Protein electrophoresis. Chromatographic and Electrophoretic Techniques. Vol. 2. (Eds. I. Smith \& J. W. T. Seakin) 4th edn. William Heinemann, London.

Sтово, J.D. (1981) Autoimmune antireceptor diseases. Hospital Practice, 16, 49.

Takeda, R., Funazu, T., Odake, K., Kawato, M., Matsuda, T. \& MURAKAMI, M. (1973) Idiopathic thrombocytopenic purpura associated with hyperthyroidism. Southern Medical Journal, 66, 553.

THOMPSON, J.A. (1964) Alterations in capillary fragility in thyroid disease. Clinical Science, 26, 55.

TOLAND, C.G. \& ASKEY, J.M. (1931) Atypical hemorrhagic purpura occurring with toxic adenoma of the thyroid gland. Mayo Clinical Proceedings, 6, 597.

Valenta, L.J., Treadwell, T., Berry, R. \& Elias, A.N. (1932) Idiopathic thrombocytopenic purpura and Graves' disease. American Journal of Hematology, 12, 69.

VANNASAENG, S., WASI, P. \& TANDHANAND, S. (1975) Hyperthyroidism in association with idiopathic thrombocytopenic purpura. Journal of the Medical Association of Thailand, 58, 97.

(Accepted 1 May 1984) 